\title{
BUSINESS MODEL CHANGE OF PRINTED NEWSPAPERS IN THE INTERNET AGE: THE NEW YORK TIMES CASE ${ }^{1}$
}

\section{O IMPACTO DA INTERNET NOS MODELOS DE NEGÓCIO DOS JORNAIS IMPRESSOS: O CASO DO JORNAL NEW YORK TIMES}

\author{
Humberto Elias Garcia Lopes \\ PPGA-PUC Minas \\ heglopes@gmail.com \\ Bruno Henrique Watté \\ PUC Minas \\ bruno.watte@gmail.com \\ Marlusa de Sevilha Gosling \\ UFMG \\ mg.ufmg@gmail.com
}

Submissão: $19 / 09 / 2018$

Aprovação: $02 / 04 / 2020$

\begin{abstract}
The diffusion of broadband internet services has brought about substantial changes in the business environment of traditional newspaper companies. Until then, they had sustained their operations by selling advertisements in their printed newspapers. Still, its readers shifted their habits and began to consume the online news provided by an increasing number of competitors. Consequently, managers had to change the business models of traditional newspaper companies through choices focused on meeting the controllers' short and medium-term demands. This paper analyzes the situation experienced by the New York Times, whose managers had to make choices about the new configuration of the company's business model, adjusting it both to the environment and the expectations of readers and controllers. We collected the data from the New York Times reports published between 2003 and 2012. Subsequently, we analyzed these data through the integrated activities framework and the theory of modal aspects. The results indicate that the managers changed the company's business model through choices that aimed to meet the short and medium-term demands of the controllers. Hence, the new model had limitations that would need further changes shortly.
\end{abstract}

KEYWORDS: business models, strategy, Internet, online newspapers, reformational philosophy.

\section{RESUMO}

A difusão dos serviços de Internet de banda larga trouxe mudanças substanciais no ambiente de negócios das empresas tradicionais de jornais. Até então, eles mantinham suas operações vendendo anúncios em seus jornais impressos. Ainda assim, seus leitores mudaram seus hábitos e 
começaram a consumir as notícias on-line fornecidas por um número crescente de concorrentes. Consequentemente, os gerentes tiveram que mudar os modelos de negócios das empresas tradicionais de jornais por meio de escolhas focadas em atender às demandas de curto e médio prazo dos controladores. Este artigo analisa a situação vivida pelo New York Times, cujos gerentes tiveram que fazer escolhas sobre a nova configuração do modelo de negócios da empresa, ajustando-a tanto ao ambiente quanto às expectativas dos leitores e controladores. Coletamos os dados dos relatórios do New York Times publicados entre 2003 e 2012. Posteriormente, analisamos esses dados através do quadro de atividades integradas e da teoria dos aspectos modais. Os resultados indicam que os gerentes mudaram o modelo de negócios da empresa por meio de escolhas que visavam atender às demandas de curto e médio prazo dos controladores. Portanto, o novo modelo tinha limitações que precisariam de mudanças adicionais em breve.

Palavras-chave: Modelo de Negócios. Estratégia. Internet. Jornais on-line. Filosofia reformacional.

\section{INTRODUCTION}

In recent years, traditional journalistic companies have been dealing with massive changes in their markets (RIPOLLÉS-CASERO; IZQUIERDO-CASTILLO, 2013). The rapid spread of broadband internet has attracted a large number of companies that provide online news services on their portals at low prices to their readers. These new competitors have become threats to business models focused on combining printed newspapers with paid advertisements. Concurrently, the controllers of these companies began to pressure their managers to change the logic of capturing value to maintain the economic viability of the business.

The theoretical debate regularly deals with these changes instrumentally, i.e., it emphasizes the redirection of the company's activities so that it can capture more value (CHATTERJEE; MATZLER, 2019; MUÑOZ; COHEN, 2018; WIRTZ; DAISER, 2018). The underlying logic is that the revision of the business model can ensure greater cohesion and coherence to these activities, improving the value proposition of the company and giving it a sustainable competitive position (WU; ZHAO; ZHOU, 2019).

On the one hand, this logic elucidates some critical aspects of managers' choices to change business models (CHRISTENSEN; BARTMAN; BEVER, 2016; JOHNSON; CHRISTENSEN; KAGERMANN, 2008). On the other hand, it reduces the debate to the economic aspect, in which these choices and their consequences are limited to the economic outcomes accomplished through more efficient and effective activities. Hence, accurate analysis of the effects of changing a business model depends on tools that can go beyond those outcomes.

The literature points out that the so-called frameworks fulfill this function because they are useful for evaluating the changes more organically. They accomplish that by describing the relationships among the components of a business model, which helps managers explore ways to create and capture value (BOCKEN et al., 2013). One of the best known is the integrated activities framework (IAF, CASADESUS-MASANELL; RICART, 2010), which identifies the interrelationships between managers' choices and their consequences. Through it, those managers can recognize the virtuous and vicious cycles that affect the capture of value. Additionally, it is conceivable to use IAF suitably for firms that need to change their business models to adjust 
them both to the new competitive environment and the demands of their controllers. Ultimately, managers' choices to change these models reflect different aspects. Hence, a proper interpretation would help them to understand the advances and limitations of the new business model.

This paper contributes to this critical debate by analyzing the results of the changes in the New York Times business model. We have chosen this company because it adequately represents the threats faced by traditional newsgroups from the entry of online news companies. Our survey used data collected from documents made publicly available by the New York Times. From them, we used the integrated activities framework to describe the relationship between the choices made by the company's managers and their consequences. Then, we distinguished the core meaning of both using the modal aspects theory (DOOYEWEERD, 2016a). The results allowed us to understand the limitations of the changes in the New York Times business model.

\section{LITERATURE REVIEW}

\subsection{The business model of traditional journalistic companies}

The literature on business models emerged in the early 1990s as a branch of the strategic management field (AMIT; MASSA, 2010). During this period, it focused on describing how technology companies captured value through business models (MASON; SPRING, 2011). Progressively, this literature has incorporated other industries and companies, giving rise to distinct and sometimes conflicting definitions of the term (FRISHAMMAR; PARIDA, 2019). Nevertheless, she reached the consensus that business models were cognitive schemes to explain how a company created, delivered, and captured value by seizing opportunities in its market (MASSA; TUCCI; AFUAH, 2017).

This definition regards that managers make choices whose consequences lead companies to capture more value, obtaining a favorable competitive position (DEMIL; LECOCQ; WARNIER, 2018; MIGOL; TRETYAK; HOLM, 2018). In doing so, these managers decide on the ideal configuration of current and future business models (MARTINS; RINDOVA; GREENBAUM, 2015). Still, the controllers' expectations in the short or medium-term constrain that decision substantially (FREUDENREICH; FREUND-LÜDEKE; SCHALTEGGER, 2019; HARRISON; BOSSE; PHILLIPS, 2010; MATOS; SILVESTRE, 2013). Consequently, a dilemma rises: even if managers understand that it is essential to change the business model more deeply, they prioritize choices that meet the most immediate demands of the controllers. Hence, they will probably have to revise that new business model in a shorter term than if it had been configured based on choices that would affect in the long term.

This dilemma is particularly relevant for companies that need to change their business models due to disruptive technologies, which cause plentiful changes in market dynamics (CHRISTENSEN; BARTMAN; BEVER, 2016; NWAIWU, 2018). That is the case with news companies. For decades, many of them developed from business models grounded on delivering printed newspapers to their readers. In economic and financial terms, those models were achievable through publicizing paid advertisements in the newspaper. However, the accelerated spread of disruptive broadband internet technology has created the conditions for other companies to offer news on their online portals, often without charging readers directly for it. 
Thus, traditional news companies progressively had to deal with a large number of new competitors who usually offered services at very low prices to readers. In that scenario, managers had to deal with pressures on two sides: 1) the readers wanted cheaper services, and 2) the controllers expected returns that would keep the business running. This pressure was reflected in managers' choices about changes in business models, leaving them focused on meeting controllers' paramount demands than extensively changing the logic of capturing value from companies.

In the literature, one way to analyze these changes more clearly is to use frameworks, defined as tools to describe the relationship between the components of a business model, helping managers explore ways to create and capture value (BOCKEN et al., 2013). There are different types of frameworks, depending on their purpose (WIRTZ, 2016). In this paper, we analyzed the case of the traditional New York Times news company through one of these frameworks, described below.

\subsection{Identifying choices and consequences with the integrated activities framework (IAF)}

The integrated activities framework (IAF, CASADESUS-MASANELL; RICART, 2010) is one of the best-known of its kind in the literature. It portrays the critical activities to capture value, i.e., the consequences of managers' choices. Those consequences appropriate one of two types. The first is the flexible ones, which occur when results are visible nearly instantly after changing one of the choices. The second is the rigid consequences, which occur when the effects of altering the choices arise after an extended period. Choices and consequences create a virtuous cycle when they strengthen themselves reciprocally and a vicious cycle in the reverse situation. In the integrated activities framework, the value capture potential of a business model correlates directly with the number of virtuous cycles.

That leads us to a significant aspect. The IAF distinguishes virtuous or vicious cycles subjectively, hardening the task of opposing business models. For example, Casadesus-Masanell and Ricart (2010) adopted that framework to analyze Ryanair's and TDC's business models. They used homogeneous criteria for identifying the cycles, assuring the comparison between those companies would be coherent. Hence, other researchers would benefit from those criteria if they wanted to apply the same framework to other firms. However, if those researches changed the criteria, that comparison would be unlikely. That would be the case if they regarded the paper from Brea-Solís and Grifell-Tatjé (2019) instead. Those authors described Kmart's business model through the IAF but applying different criteria. Consequently, researchers eager to adopt IAF for comparing the business models of those three firms would face the dilemma of deciding which set of criteria they should regard. The analysis would vary substantially depending on their decision. Additionally, this would be a trade-off situation: unless those researches decided to build up a new and unified framework, choosing option A would exclude option B promptly.

The lack of consensus on the criteria that researchers should adopt in the IAF leads to two kinds of interpretation. In the first, frameworks are the inputs to build up narratives about the causes of success or failure of business models (MAGRETTA, 2002). Conversely, the second sets out the scope of interpretation but fails in keeping criteria defined by the personal preferences of each researcher (FIELT, 2013). Hence, in both types, researchers adopt their personal preferences to analyze the frameworks, establishing little connection with previous knowledge. Consequently, the literature ends up developing weakly-articulated ideas. 
It is conceivable to minimize that obstacle through one of two alternatives. First, researchers could take a consensual set of criteria to interpret the IAF. On the one hand, this could create a stable pattern for analyzing the results. On the other hand, the development of the literature indicates that the initial obstacle would re-emerge by each researcher adopting his criteria. The second alternative is to assume a consolidated theory that employs more definite criteria to interpret the results of the IAF. In this case, there is the risk of choosing a theory that does not fit properly with the evaluation of business models. Again, this would imply that researchers were creating personal criteria. However, they might minimize the chances of dealing with that situation by adopting a theory that is broad enough to comprise several different frameworks but concurrently covering relevant and well-defined criteria for analysis. In this paper, we settled for this second alternative, interpreting the results of the IAF through the theory of modal aspects.

\subsection{The theory of modal aspects and the integrated activities framework}

The theory of modal aspects is an ontology that recognizes, appoints, and analyzes the aspects of temporal reality in the most precise way (BREEMS; BASDEN, 2014; TROOST, $2012 \mathrm{~b}$ ). It is a branch of reformational philosophy that dares the dominant Kantian and neoKantian approaches in the sciences in general. More specifically, the reformational philosophy is opposed to the idea that reason gives order and meaning to a reality that is inherently chaotic (KANT, 2008). From a reformational perspective, at first, the person already perceives the created reality as an ordered whole because he has the innate faculty to assign meaning to it. For example, even when someone comes across an unknown object, he or she can recognize its shape, colors, and size. From this, this person forms a generic image of this object and assigns meaning to it by deciding whether or not to like it or invest time in learning more about it.

That does not mean to scrutinize the most specific aspects of the object existence: until that moment, the person does not worry about its physical-chemical characteristics or the ethical and legal implications of its incorrect use. Instead, he or she perceives this object as a whole, in a moment called naïve experience (KALSBEEK, 2002). In reformational philosophy, the person scrutinizes the elements of created reality in a subsequent moment, called theoretical thinking. It decomposes an element into modal aspects, which represent its fundamental way of being. Those aspects elucidate the meaning that people assign to the elements, bringing them into existence (DOOYEWEERD, 2016a).

The theory of modal aspects states that these aspects are limited in number and organized in a fixed and accumulative order of increasing complexity. For this reason, the fifteen aspects constitute a sequence in which one aspect encompasses those that precede it - retrocipation while concurrently pointing to the next aspect in the so-called anticipation (DOOYEWEERD, 2016b). Retrocipation and anticipation are two of the three moments of a modal aspect. For the reformational philosophy, the moment is what delimits and provides meaning to each of these aspects (KALSBEEK, 2002).

The third of these moments is the meaning-nucleus. It guarantees the distinctive character of a specific aspect, without reducing it to any of the others (TROOST, 2012a). Taking the legal aspect as an example, we see that its meaning-nucleus lies in proportional retribution. Accordingly, a structure of individuality that incorporates this aspect seeks the promotion of justice primarily. Likewise, this aspect reverses those that precede it, creating an irreducible 
structure of individuality, i.e., that is not only explained from a legal perspective. This structure is part of a created reality that also incorporates aesthetic, economic, social, linguistic aspects, and so on, until reaching the first of them, which is the numerical aspect. Table 1 shows the order of the modal aspects with their respective meaning-nuclei.

Table 1 - Modal Aspects and their Meaning-Nuclei

\begin{tabular}{ll}
\hline \multicolumn{1}{c}{ Modal aspect } & \multicolumn{1}{c}{ Meaning-nucleus } \\
\hline Pistic & Faith, certainty, security \\
Ethical & Love, loyalty \\
Legal & Retribution, justice, legality \\
Aesthetic & Beauty, harmony \\
Economic & Frugality, moderation \\
Social & Social relations \\
Language & Symbolic meaning, language \\
Training & Formative power or control, culture \\
Analytical Logic & Analysis, identification of differences \\
Sensitive & Sensitivity, emotion, affection \\
Biotic & Organic life, vitality \\
Physical & Energy, strength, change, dynamics \\
Cinematography & Mobility, mechanical movement \\
Space & Continuous Extension \\
Numeric & Number, discrete quantity \\
\hline \hline
\end{tabular}

Source: adapted from Troost (2012, p. 77).

In this paper, we employed this theory to expand the analysis of the IAF. Our objective was to go beyond the economic aspect of choices and consequences, evaluating them under a broader perspective. The following sections present the results.

\section{METHODOLOGY}

We analyzed qualitatively the changes managers have made in the New York Times business model to react to competition from online news portals. Accordingly, we worked on a single case study (EDMONDS; KENNEDY, 2017), collecting data from official New York Times reports published between 2002 and 2011. This period encompassed the first changes in the newspaper's business model and its early effects.

The reports comprised the data to identify the choices of managers and their consequences. After collecting the data, we reassessed it to eliminate the ephemeral choices, i.e., those that had no continuity over the years surveyed. That was a necessary procedure because we supposed that they would hardly change the newspaper's business model substantially.

Afterward, we re-evaluated the data, gathering the choices to eliminate duplicity. We then created a list with enduring choices that had a significant effect on changing the NYT business model. We use this list to re-analyze the reports, classifying the consequences as rigid or flexible. To reduce subjectivity as much as possible, we have consensually defined the best classification for each of them, since Casadesus-Masanell and Ricart (2010a) have not defined procedures for 
this. After completing this step, we selected the most suitable choices and consequences, following the recommendation of these authors. After that, we draw up a descriptive diagram of the new NYT business model, following the original notation of the IAF.

The following procedure led us to evaluate the choices and consequences from the perspective of the modal theory. Firstly, we identified the meaning-nucleus that qualified each choice, which covered from the formative aspect to the pistical.

Additionally to the specific analysis of the framework, this paper includes more comprehensive information about the NYT, collected from two sources: 1) annual reports to shareholders for the past ten years, required by the United States Securities and Exchange Commission (SEC) and 2) specialized newspapers and magazines. In this case, these sources also allowed us to confirm, detail, or compare the information collected from the official reports.

\section{DATA ANALYSIS}

\subsection{The history of the New York Times}

The New York Times (NYT) was founded in 1851 by journalists Henry Jarvis Raymond and George Jones. In 1896, Adolph S. Ochs purchased the company that remained under the control of the Ochs-Sulzberger family ever since. Over its first 150 years of activity, the NYT has become influential in the United States, to some extent, thanks to its business model focused on quality journalism.

The outcomes of this model during the 1980s and 1990s encouraged managers to expand the circulation of printed newspapers. Consequently, the NYT expanded its area of operation, reaching 315 metropolitan regions of the United States and ceasing to be a local newspaper. Concurrently, the choice for quality journalism continued to benefit the newspaper, providing it widely-acclaimed recognition: the NYT won 112 Pulitzer Prizes, the top prize in American journalism (THE NEW YORK TIMES COMPANY, 2013). That made him the most massive winner of this award and reinforced its image, reputation, and revenues.

Nevertheless, this business model has not helped managers realize the extent of the ongoing changes in the market. As the paper strengthened its image and reputation, Americans acquired plans for broadband Internet access. Companies such as AltaVista, Yahoo!, AOL, and Google took advantage of this technological development to offer fast and customized news searches. Progressively, their users realized that the news that interested them was first published on the Internet, not in the printed newspapers. Consequently, online news portals gradually increased their market share until they became a threat to printed newspapers.

The NYT's first effective reaction to this threat took place in 1996 with the launch of the newspaper's website. This new service combined free content with paid advertising, which created additional revenue streams. Simultaneously, the managers kept investing in the expansion of the printed edition's area of operation, which they considered accountable for the newspaper's satisfactory economic performance (LEWIS, 1996; THE NEW YORK TIMES COMPANY, 2004).

Nevertheless, that choice caused three problems. The first was the substantial reduction of readers in the New York metropolitan area, NYT's primary market. The second was the decrease in the total volume of advertisements, notably in its most important means of dissemination: the 
classifieds section. Ultimately, total revenue only continued to grow because managers had chosen to readjust advertisement prices periodically. The third problem was the consistent and steady growth of online readers of the Nytimes.com website, which was hindering sales of the printed edition (Table 2).

Table 2 - New York Times internal performance indicators (1998-2003)

\begin{tabular}{l|r|r|r|r|r|r}
\hline \multicolumn{1}{c|}{ Indicator } & \multicolumn{1}{c}{1998} & 1999 & 2000 & 2001 & 2002 & 2003 \\
\hline $\begin{array}{l}\text { Circulation in the New York metropolitan } \\
\text { area (in thousands) }\end{array}$ & 664 & 666 & 662 & 663 & 622 & 600 \\
$\begin{array}{l}\text { The total volume of paid advertisements } \\
\text { (in thousands of inches) }\end{array}$ & 2.977 & 3.134 & 3.230 & 2.626 & 2.473 & 2.375 \\
& & & & & \\
National announcements & 1.393 & 1.582 & 1.692 & 1.370 & 1.346 & 1.334 \\
Local ads (New York City) & 587 & 567 & 574 & 475 & 434 & 411 \\
Classified Ads & 997 & 985 & 964 & 781 & 693 & 630 \\
$\begin{array}{l}\text { Nytimes.com Web Site Audience (in } \\
\text { thousands of users) }\end{array}$ & 5,6 & 10,1 & 14,3 & NA & NA & NA \\
\hline \hline
\end{tabular}

Source: Research data. Note: NA indicates data not available. The total volume of ads is the sum of national, local, and classified ads.

This progression in the number of online readers was consistent with the growth of Internet users, who were 35\% of the US population in 1997 and became $60 \%$ in 2003 (MADDEN, 2006). Despite this change in their business scenario, managers continued to favor the printed edition. Still, performance between 2003 and 2005 fell short of expectations, convincing controllers to demand shifts in the business model. For them, NYT should become a broad-based and diversified media organization (THE NEW YORK TIMES COMPANY, 2006).

\subsection{Changing the NYT business model}

Initially, managers made six basic choices for changing the NYT business model. The first was the acquisition of internet companies, such as the About.com website. The purpose was to absorb the digital competence of those acquired to compete more efficiently and effectively in the online advertising revenue market. The second choice was to launch the TimesSelect service, a pioneer in the US market that charged a subscription for access to the content of the newspaper's leading columnists. The third was to create a research and development center for projects focused on new digital technologies that could put the newspaper ahead of its competitors. The fourth choice was to reduce costs, without harming the quality of journalism. The fifth choice was to diversify the content distribution platforms, developing applications for ereaders and mobile devices (THE NEW YORK TIMES COMPANY, 2001, 2004, 2005, 2006, 2007, 2008, 2009, 2010, 2011, 2012).

These first five choices had positive results in the newspaper's performance (Table 3). However, the sixth choice had the most significant impact: to make printed circulation more profitable. Throughout its history, the NYT has charged lower prices in the printed edition, transferring the cost to its advertisers. Managers changed this condition when advertising revenue 
started to have a downward trend: from 2006 on, they raised prices, which directly impacted circulation revenue (Table 3 ).

Table 3 - Circulation and circulation revenue of the New York Times

\begin{tabular}{l|r|r|r|r|r|r|r|r}
\hline \hline \multicolumn{1}{c|}{ Circulation } & \multicolumn{1}{c|}{2003} & \multicolumn{1}{c|}{2004} & \multicolumn{1}{c|}{2005} & \multicolumn{1}{c|}{2006} & \multicolumn{1}{c|}{2007} & \multicolumn{1}{c}{2008} & \multicolumn{1}{c}{2009} & \multicolumn{1}{c}{2010} \\
\hline Weekly & 1.132 & 1.125 & 1.136 & 1.104 & 1.067 & 1.034 & 959 & 906 \\
Sunday & 1.682 & 1.670 & 1.685 & 1.638 & 1.530 & 1.451 & 1.405 & 1.357 \\
Total circulation & $\mathbf{2 . 8 1 4}$ & $\mathbf{2 . 7 9 5}$ & $\mathbf{2 . 8 2 1}$ & $\mathbf{2 . 7 4 2}$ & $\mathbf{2 . 5 9 7}$ & $\mathbf{2 . 4 8 5}$ & $\mathbf{2 . 3 6 4}$ & $\mathbf{2 . 2 6 3}$ \\
Circulation revenue & 623 & 616 & 616 & 637 & 646 & 668 & 684 & 684 \\
\hline \hline
\end{tabular}

Source: Research data. Note: circulation figures are in millions. Circulation revenue is in millions of dollars.

Despite these results, the controllers believed that the changes in the business model needed to advance. According to them, the growth in circulation revenue did not fully cover the losses that the printed paper had with the online news portals. Moreover, the increase in the number of readers who subscribed to the NYT for two or more years in a row $(830,000$ in 2008 against 650,000 in 2006) could not persist in the face of the accelerated popularization of the Internet and online news consumption. These reasons led managers to change the business model again, adopting partial content charging (metered paywall). Consequently, the NYT was the first major newspaper to adopt this model, in which the reader could access a certain monthly quota of news for free. If he or she wanted to read more, he or she should pay for the subscription to access the full content.

\subsection{Analysis of the IAF with the theory of modal aspects}

This history of the NYT provided the information for us to use the IAF to describe the relationships between the leading choices and consequences made by its managers. Figure 1 shows the result. 
Figure 1 - Choices and consequences in the new New York Times business model

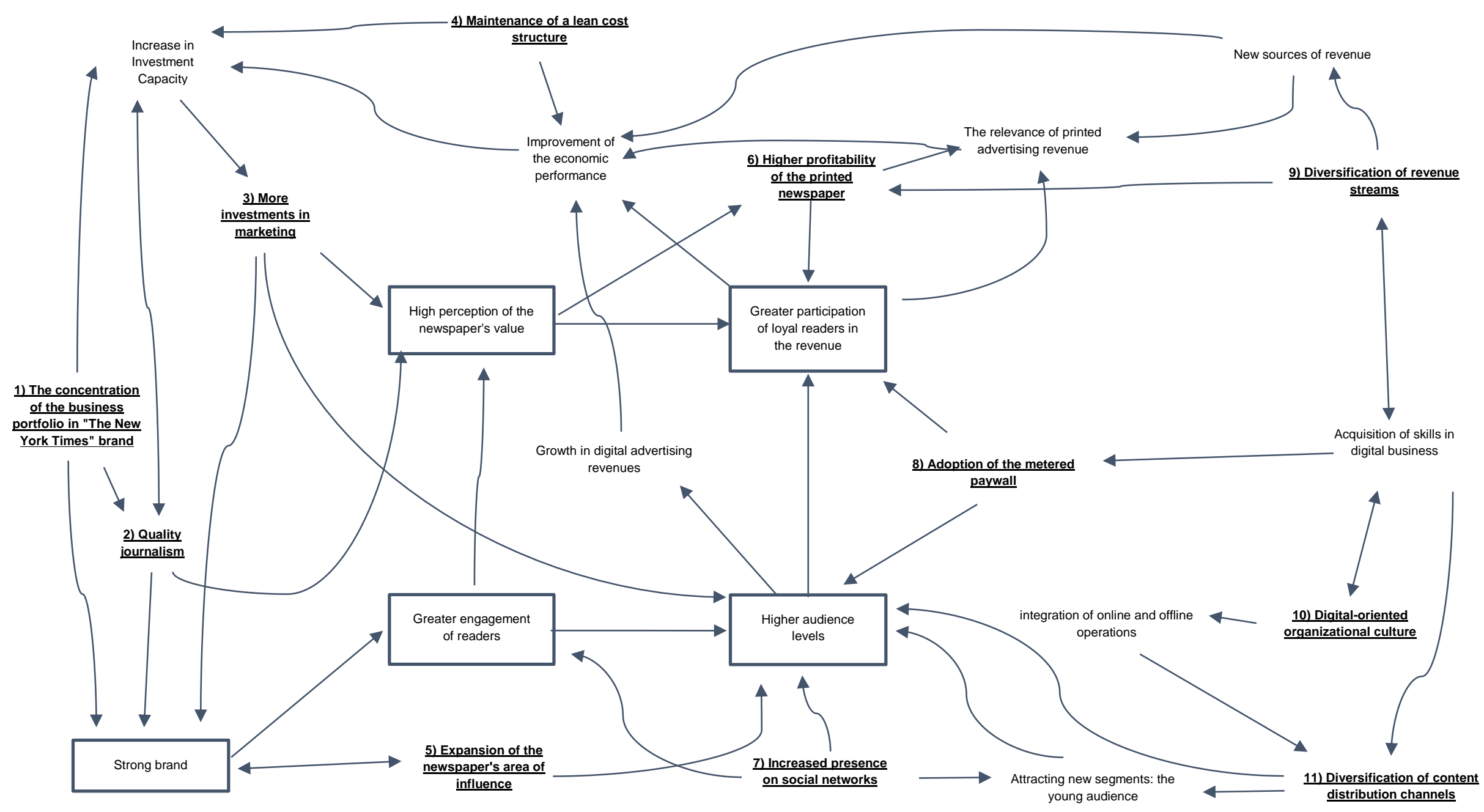

Source: Research data. Notes: bold and underlined texts indicate choices. Texts in the boxes: rigid consequences. Otherwise: flexible conseauences. 
The IAF (Figure 1) describes not only the interrelationships between choices and consequences but also the virtuous circles of the new NYT business model configuration. Thus, some choices are directly or indirectly self-reinforcing.

In the first case, there are the relationships between choices 1 (concentration of the business portfolio in the NYT brand) and 2 (quality journalism), as well as between choices 9 (diversification of revenue streams) and 6 (higher profitability of the printed newspaper). In the second case, we identified choices that indirectly formed virtuous cycles: choice 4 (maintenance of a lean cost structure) reinforced choices 1 and 2 through their consequences. Choice 3 (more investments in marketing) did the same for choice 6 . Indirect virtuous cycles also arose among choices 11 (diversification of content distribution channels) and 7 (increased presence on social networks), 9 and 10 (digital-oriented organizational culture), 8 (adoption of the metered paywall), 4 (maintenance of a lean cost structure), and 3 more investments in marketing).

The traditional analysis of the IAF would lead us to the conclusion that the NYT's new business model was potentially beneficial to the company because it incorporated these virtuous cycles. Consequently, it could increase the capture of value, becoming more competitive, and meeting the demands of controllers. However, the theory of modal aspects has given us a more in-depth interpretation of the results, allowing us to identify the limitations of the new business model acutely.

On this account, by using this theory, we identified the qualifying modal aspects determined by the meaning-nuclei of each choice and consequence. Therefore, we could analyze their central mode of existence promptly. Table 4 exhibits the results.

Table 4 - Choices and consequences with their qualifying modal aspects

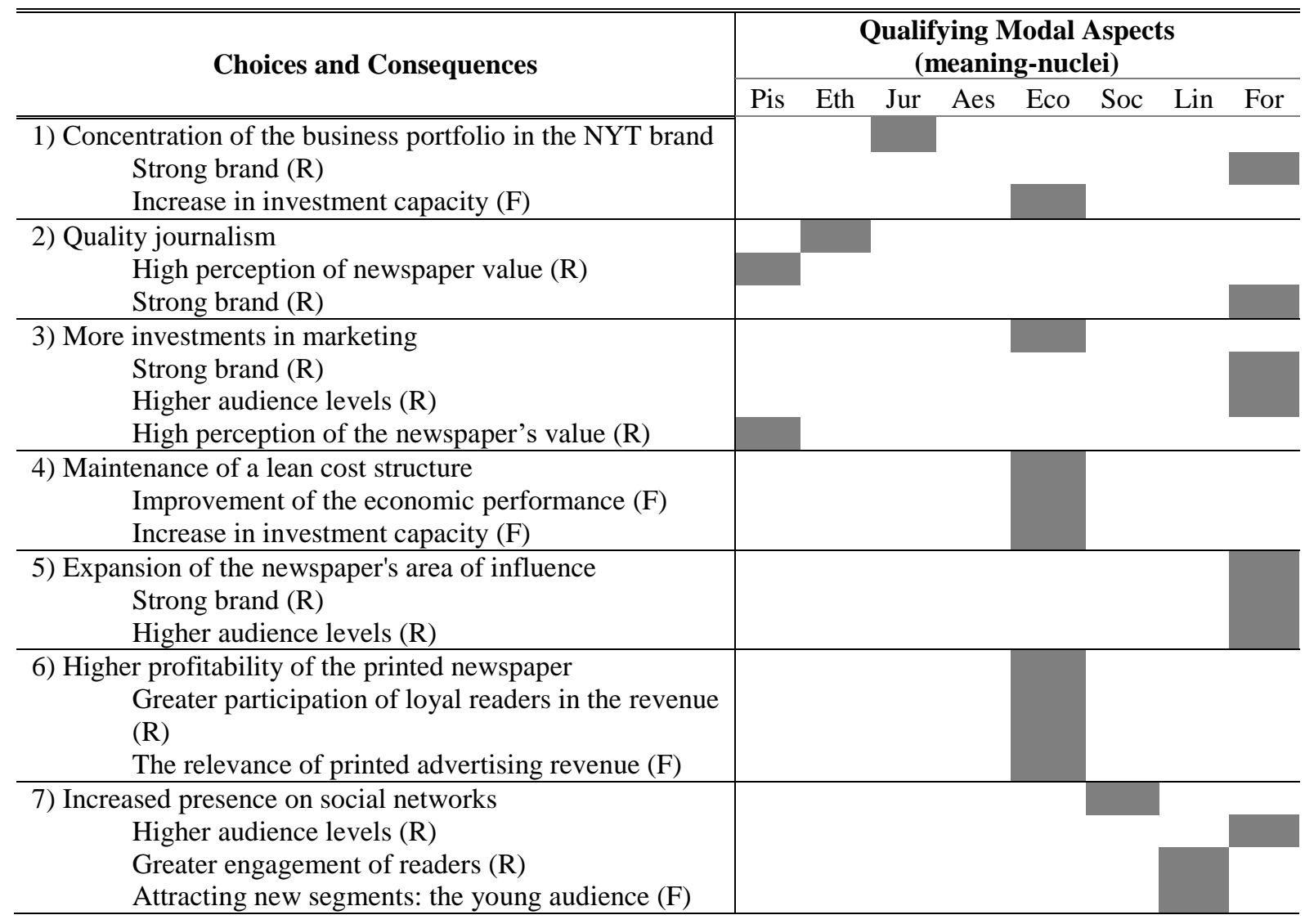




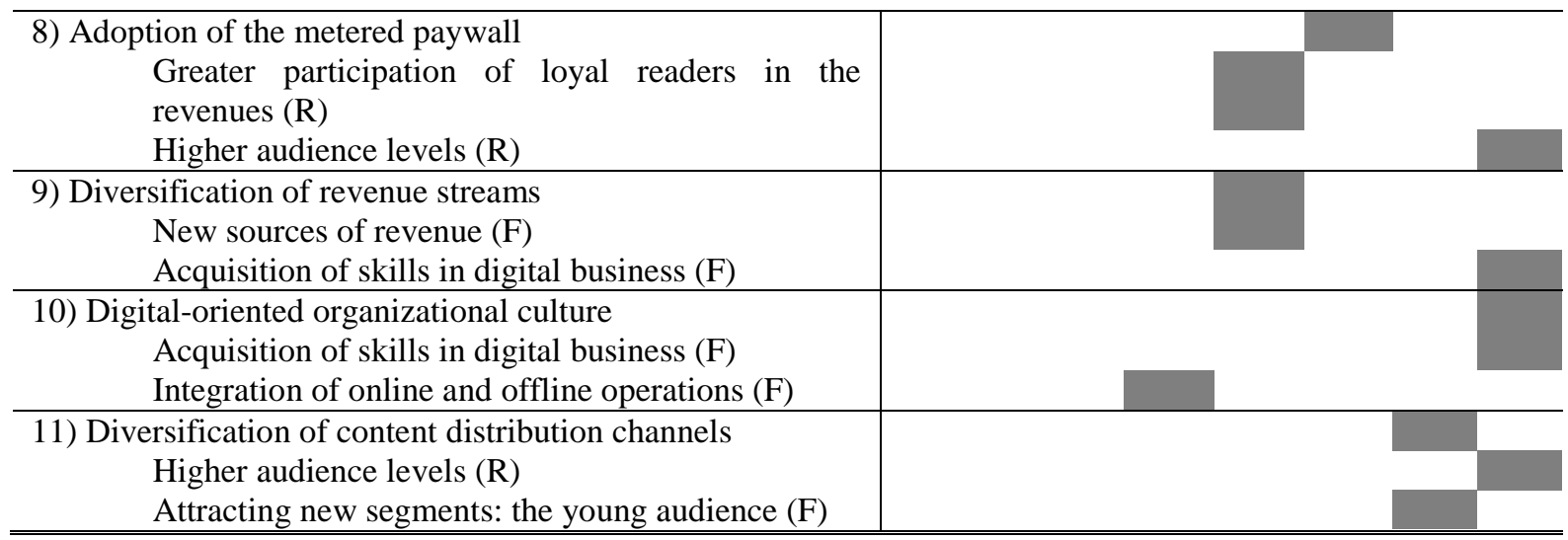

Source: research data. Note: $R=$ rigid consequence. $F=$ flexible consequence. Pis $=$ pistic. Eth $=$ ethical . Jur $=$ legal. Aes $=$ aesthetic. Eco $=$ economic. Soc $=$ social. Lin $=$ lingual. For $=$ formative.

The meaning-nuclei of the modal aspects ranging from the formative to the pistical qualified the choices and consequences. The above aspects are included in each one of them by the retrocipation, but they are not their qualifiers.

In the analysis usually adopted in the literature, the choices and their respective consequences bear solely on economic logic, in which managers would seek to maximize the value capture of the NYT business model. The theory of modal aspects allowed us to avoid this limitation by extending the analysis. Choice 1 (concentration of the business portfolio in the NYT brand) is juridically qualified because it has implied a change in the formal and legal structure of the NYT. It thereby associated with the rigid consequence "strong brand," which was qualified by the formative aspect because it provided the NYT higher capacity to influence the perception of its readers about the created reality. Choice 1 also connected to the flexible consequence "increase in investment capacity", which was economically qualified by focusing on more effective allocation of company resources.

Choice 2 (quality journalism) could have its mode of existence reduced to economic logic. However, we recognized that its core ethical meaning bounded it since the quality of journalism in the newspaper grounded on a love of truth, which should arise in the articles published. This choice also manifested all the other fourteen aspects, such as the pistical (managers have faith that it may lead the NYT to the results they expect) and the legal (quality and credibility decrease the chances of lawsuits for publishing unproven evidence-based stories). However, we conceded the ethical modal aspect of being the dominant one, being the qualifier.

Concurrently, this choice associated with the rigid consequence "high perception of the newspaper's value," qualified by its pistical aspect. The reason was that the value attributed to the newspaper by its readers is an act of faith: the expectation that the benefit of accessing the published articles is higher than the cost of purchasing a copy. Choice 2 also connected to the rigid consequence "strong brand," formative qualified for the reasons presented above.

Choice 3, "more investments in marketing," had the rigid consequences of "strong brand," "higher audience levels", and "high perception of the newspaper's value". The formative aspect qualified the first two since the branding and the higher audience implied the more significant influence of the NYT on its readers' perception about the created reality. The last consequence was qualified pistically, as stated previously.

Choice 4 (maintenance of a lean cost structure) and its flexible consequences "improvement of the economic performance" and "increase in investment capacity" was qualified 
by the economic aspect, representing more significant moderation in the use of the company's resources. The formative aspect qualified Choice 5 (expansion of the newspaper's area of influence) and its two rigid consequences for the reasons explained previously. Choice 6 was the search for higher profitability of the printed newspaper, which was economically qualified as well as its rigid consequence "greater participation of loyal readers in the revenue" and its flexible consequence "relevance of printed advertising revenue."

The social aspect qualified Choice 7 (increased presence on social networks) because its core was in the company's relations with its readers and with other organizations or institutions such as competitors, press, government agencies, among others. It connected with the rigid consequence "greater engagement of readers" and with the flexible consequence "attracting new segments: the young audience". The lingual aspect qualified both because they primarily involved better communication skills of the NYT with these new readers. Choice 7 also connected with the rigid consequence, "higher audience levels", which qualified formatively for the reasons stated before.

The social aspect qualified Choice 8 because the adoption of the metered paywall represented a change in the company's relationship with its stakeholders. It connected to the two rigid consequences analyzed before. Choice 9 (diversification of revenue streams) and its first flexible consequence "new sources of revenue" qualified economically. The second flexible consequence, "acquisition of skills in digital business," was qualified by the social aspect for the same reason described in this paragraph.

Choice 10 and its flexible consequence "acquisition of skills in digital business" were qualified by the social aspect because they attempted to increase the NYT's influence on how its readers perceived the created reality. The flexible consequence "integration between online and offline operations" was aesthetically qualified because we concluded that it focused on greater harmony between the company's internal processes. Finally, Choice 11 was qualified by the linguistic aspect because the diversification of the content distribution channels involved more exceptional communication of the company with its readers. The consequences of this choice were qualified by the formative and lingual aspects of the reasons already provided.

\section{DISCUSSION OF RESULTS}

The change in NYT's business model occurred because its managers made decisions around two objectives: create more value for controllers and maintain the quality of journalism. The conventional analysis of the IAF indicates that this change has created a business model with virtuous cycles formed by activities that strengthen themselves (Figure 1). According to the literature, this would indicate that the NYT has increased its potential to capture value.

Though, the qualifying modal aspects helped us to identify significant limitations in the NYT's new business model. The choices and consequences were qualified mainly by the economic and formative aspects, showing that the managers focused on improving the economic and financial performance of the company and expanding its sphere of influence over the readers. On the one hand, this is consistent with the NYT's market situation, which demanded a strong reaction to the threat posed by the growth of online news companies. On the other hand, it reveals the attachment of managers to choices that take effect more quickly.

The business model reflects the logic by which a company captures value in its market. Consequently, changing it may cause more lasting effects on this company as a whole. When NYT managers embraced this path, they expected to reply to the pressures of controllers in the short and medium-term. By doing so, they have changed the logic of value creation - the effects 
of which are more lasting - based on immediate demands. Thus, the changes in the business model have left out aspects that could lead to more profound changes and bring more lasting benefits.

That is clearer when we analyze the modal aspects less associated with the choices made by managers and their consequences. The aesthetic aspect would be relevant both to harmonize activities and to create more attractive products for readers. Nevertheless, he qualified only for the flexible consequence of Choice 10. The legal aspect is crucial to redefine the formal organization of the company, giving it the conditions to implement changes that would give it legal certainty. Notwithstanding, this aspect qualified only Choice 2.

Ethics are often held essential for the performance of companies, notably according to those who are opinion formers. Thus, one would expect any change in the business model of a journalistic company like the NYT to pay close attention to the ethical aspect. Nonetheless, this did not happen, as he qualified only Choice 1. Lastly, a newspaper needs to cultivate positive expectations from its readers about the quality of its product because it affects the capture of value. Hence, the new business model should incorporate choices and consequences qualified by the pistical aspect, but this occurred only twice.

Summing, the change in NYT's business model reflects the usual behavior of managers to make decisions that have more immediate effects. That makes the new model perhaps insufficient to deal with future problems, requiring additional changes in the logic of value creation.

\section{CONCLUSION}

This article analyzed the NYT's new business model, resulting from managers' choices to respond to the threats posed by online news companies. Although this new model helped the company to redirect its operations, incorporating the digital market, it presented limitations that did not lead to a sustainable change.

From the typical literature perspective, the analysis of the IAF indicates that the new NYT business model has succeeded in creating virtuous cycles by combining the online and printed versions of the newspaper. Consequently, the company would be better able to respond effectively to the threat posed by its competitors.

However, regarding the qualifying modal aspects of these choices and consequences, it appears that managers have created the new business model to meet short and medium-term demands. Thus, the logic of value capture was changed to improve economic and financial results quickly and to stop the loss of readers. The little attention given by managers to the pistical, ethical, legal, and aesthetic aspects of the new business model reinforces that statement.

The company had to adjust to a new scenario, in which printed newspapers were losing readers to online news. This change has profound implications on the structure and way of acting of a traditional company like the NYT. Thus, their managers would make more considerable changes to the company's business model. However, they preferred to follow traditional management logic, concentrating on creating conditions to meet the immediate demands of the controllers. In doing so, those managers missed the opportunity to establish a value capture logic that would leave the NYT in a sustainable competitive position in the long term. 


\section{REFERENCES}

BOCKEN, Nancy et al. A value mapping tool for sustainable business modelling. Corporate Governance, v. 13, n. 5, p. 482-497, 2013.

BREA-SOLÍS, Humberto; GRIFELL-TATJÉ, Emil. A business model analysis of Kmart's downfall. International Journal of Retail \& Distribution Management, v. 47, n. 2, p. 111-128, 2019.

BREEMS, Nick; BASDEN, Andrew. Understanding of computers and procrastination: a philosophical approach. Computers in Human Behavior, v. 31, p. 211-223, 2014.

CASADESUS-MASANELL, Ramon; RICART, Joan E. From strategy to business models and onto tactics. Long Range Planning, v. 43, n. 2-3, p. 195-215, 2010.

CHATTERJEE, Sayan; MATZLER, Kurt. Simple rules for a network efficiency business model: the case of Vizio. California Management Review, v. 61, n. 2, p. 84-103, 2019.

CHRISTENSEN, Clayton M.; BARTMAN, Thomas; BEVER, Derek Van. The Hard Truth About Business Model Innovation. MIT Sloan Management Review, v. 58, n. Fall, 2016. Disponível em: <http://sloanreview.mit.edu/article/the-hard-truth-about-business-modelinnovation/>.

DEMIL, Benoît; LECOCQ, Xavier; WARNIER, Vanessa. "Business model thinking”, business ecosystems and platforms: the new perspective on the environment of the organization. Management, v. 21, n. 4, p. 1213-1228, 2018.

DOOYEWEERD, Herman. A new critique of theoretical thought. Ontario: Paidea Press, 2016a. v. 2.

DOOYEWEERD, Herman. The modal structures of meaning. A new critique of theoretical thought. Collected works - Series A. Jordan Station: Paidea Press, 2016b. v. 2. p. 55-180.

EDMONDS, W. Alex; KENNEDY, Thomas D. Single-case approach. An applied guide to research designs: quantitative, qualitative, and mixed methods. 2. ed. Los Angeles: Sage, 2017. p. 103-115.

FIELT, Erwin. Conceptualising business models: definitions, frameworks and classifications. Journal of Business Models, v. 1, n. 1, p. 85-105, 2013.

FREUDENREICH, Birte; FREUND-LÜDEKE, Florian; SCHALTEGGER, Stefan. A stakeholder theory perspective on business models: value creation for sustainability. Journal of Business Ethics, 2019.

FRISHAMMAR, Johan; PARIDA, Vinit. Circular business model transformation: a roadmap for 
incumbent firms. California Management Review, v. 61, n. 2, p. 1-29, 2019.

HARRISON, J.; BOSSE, D.; PHILLIPS, R. Managing for stakeholders, stakeholder utility functions, and competitive advantage. Strategic Management Journal, v. 31, n. 1, p. 58-74, 2010.

JOHNSON, Mark W.; CHRISTENSEN, Clayton M.; KAGERMANN, Henning. Reinventing your business model. Harvard Business Review, v. 86, n. 12, p. 50, dez. 2008.

KALSBEEK, L. Contours of a Christian philosophy: an introduction to Herman Dooyeweerd's thought. Lewiston: Edwin Mellen Press, 2002.

KANT, Immanuel. Critique of pure reason. New York: Penguin Classics, 2008.

LEWIS, Peter H. The New York Times introduces a web site. The New York Times, New York, 1996. ArchivesDisponível em: <https://www.nytimes.com/1996/01/22/business/the-new-yorktimes-introduces-a-web-site.html>. Acesso em: 29 ago. 2018.

MADDEN, Mary. Internet penetration and impact. , Report. [S.1.]: Pew Research Center, 2006. Disponível em: <http://www.pewinternet.org/2006/04/26/internet-penetration-and-impact/>.

MAGRETTA, Joan. Why business model matter. Harvard Business Review, v. May, n. 5, p. 3-8, 2002.

MARTINS, Luis L.; RINDOVA, Violina P.; GREENBAUM, Bruce E. Unlocking the Hidden Value of Concepts: A Cognitive Approach to Business Model Innovation. Strategic Entrepreneurship Journal, v. 9, n. 1, p. 99-117, 2015.

MASON, Katy; SPRING, Martin. The sites and practices of business models. Industrial Marketing Management, v. 40, n. 6, p. 1032-1041, 2011.

MASSA, Lorenzo; TUCCI, Christopher; AFUAH, Allan. A critical assessment of business model research. Academy of Management Annals, v. 11, n. 1, p. 73-104, 2017.

MATOS, Stelvia; SILVESTRE, Bruno S. Managing stakeholder relations when developing sustainable business models: the case of the Brazilian energy sector. Journal of Cleaner Production, v. 45, p. 61-73, 2013.

MIGOL, Ekaterina; TRETYAK, Olga; HOLM, Anna B. Business model design themes, value propositions and firm performance. Journal of Business Models, v. 6, n. 2, p. 54-58, 2018.

MUÑOZ, Pablo; COHEN, Boyd. A compass for navigating sharing economy business models. California Management Review, v. 61, n. 1, p. 114-147, 2018.

NWAIWU, Fortune. Analysis of emerging business models of companies in the era of the digital economy. Journal of Sustainable Development, v. 8, n. 20, p. 18-27, 2018. 
OSTERWALDER, Alexander; PIGNEUR, Yves; TUCCI, Christopher L. Clarifying business models: origins, present, and future of the concept. Communications of the Association for Information Systems, v. 15, n. 1, p. 1-25, 2005.

RIPOLLÉS-CASERO, Andreu; IZQUIERDO-CASTILLO, Jessica. Between decline and a new online business model: the case of the Spanish newspaper industry. Journal of Media Business Studies, v. 10, n. 1, p. 63-78, 2013.

SHAFER, Scott M.; SMITH, H. Jeff; LINDER, Jane C. The power of business models. Business Horizons, v. 48, n. 3, p. 199-207, 2005.

THE NEW YORK TIMES COMPANY. 2002 annual report. . New York: [s.n.], 2001. Disponível em: <https://investors.nytco.com/investors/financials/annual-reports/default.aspx>. Acesso em: 10 set. 2018.

THE NEW YORK TIMES COMPANY. 2003 annual report. . New York: [s.n.], 2004. Disponível em: <https://investors.nytco.com/investors/financials/annual-reports/default.aspx>. Acesso em: 10 set. 2018.

THE NEW YORK TIMES COMPANY. 2004 annual report. . New York: [s.n.], 2005. Disponível em: <https://investors.nytco.com/investors/financials/annual-reports/default.aspx>. Acesso em: 10 set. 2018.

THE NEW YORK TIMES COMPANY. 2005 annual report. . New York: [s.n.], 2006. Disponível em: <https://investors.nytco.com/investors/financials/annual-reports/default.aspx>. Acesso em: 10 set. 2018.

THE NEW YORK TIMES COMPANY. 2006 annual report. . New York: [s.n.], 2007. Disponível em: <https://investors.nytco.com/investors/financials/annual-reports/default.aspx>. Acesso em: 10 set. 2018.

THE NEW YORK TIMES COMPANY. 2007 annual report. . New York: [s.n.], 2008. Disponível em: <https://investors.nytco.com/investors/financials/annual-reports/default.aspx>. Acesso em: 10 set. 2018.

THE NEW YORK TIMES COMPANY. 2008 annual report. . New York: [s.n.], 2009. Disponível em: <https://investors.nytco.com/investors/financials/annual-reports/default.aspx>. Acesso em: 10 set. 2018.

THE NEW YORK TIMES COMPANY. 2009 annual report. . New York: [s.n.], 2010. Disponível em: <https://investors.nytco.com/investors/financials/annual-reports/default.aspx>. Acesso em: 10 set. 2018.

THE NEW YORK TIMES COMPANY. 2010 annual report. . New York: [s.n.], 2011. Disponível em: <https://investors.nytco.com/investors/financials/annual-reports/default.aspx>. 
Acesso em: 10 set. 2018.

THE NEW YORK TIMES COMPANY. 2011 annual report. . New York: [s.n.], 2012. Disponível em: <https://investors.nytco.com/investors/financials/annual-reports/default.aspx>. Acesso em: 10 set. 2018.

THE NEW YORK TIMES COMPANY. Pulitzer Prizes. New York, 2013.

TROOST, Andree. Cosmology: the series of modal aspects. What is reformational philosophy? An introduction to the cosmonomic philosophy of Herman Dooyeweerd. Ontario: Paidea Press, 2012a. p. 71-86.

TROOST, Andree. What is reformational philosophy? An introduction to the cosmonomic philosophy of Herman Dooyeweerd. Ontario: Paidea Press, 2012b.

WIRTZ, Bernd W. Business model management: design process instruments. 2. ed. Wiesbaden: Speyer, 2016.

WIRTZ, Bernd W.; DAISER, Peter. Business model development: a customer-oriented perspective. Journal of Business Models, v. 6, n. 3, p. 22-44, 2018.

WU, Xiaobo; ZHAO, Ziyi; ZHOU, Banghao. Legitimacy in adaptative business model innovation: an investigation of academic ebook platforms in China. Emerging Markets Finance \& Trade, v. 55, n. 4, p. 719-742, 2019.

ZOTT, Christoph; AMIT, Raphael; MASSA, Lorenzo. The business model: theoretical roots, recent developments, and future research. Working Paper, $\mathrm{n}^{\mathrm{o}}$ WP-862. Barcelona: IESE, 2010.

\footnotetext{
${ }^{1}$ The authors acknowledge the financial support provided by FAPEMIG (APQ-03474-17) and CNPq (442900/2014-7) to the research that originated this paper.
} 